\title{
Strong linkages between surface and deep-water dissolved organic matter in the East/Japan Sea
}

\author{
Tae-Hoon Kim ${ }^{1}$, Guebuem Kim², Yuan Shen ${ }^{3}$, and Ronald Benner ${ }^{3,4}$ \\ ${ }^{1}$ Department of Earth and Marine Sciences, Jeju National University, Jeju, 63243, Republic of Korea \\ ${ }^{2}$ School of Earth and Environmental Sciences/Research Institute of Oceanography, Seoul National University, 1 Gwanak-ro, \\ Gwanak-gu, Seoul, 08826, Republic of Korea \\ ${ }^{3}$ Marine Science Program, University of South Carolina, Columbia, South Carolina 29208, USA \\ ${ }^{4}$ Department of Biological Sciences, University of South Carolina, Columbia, South Carolina 29208, USA
}

Correspondence to: Tae-Hoon Kim (thkim@jejunu.ac.kr)

Received: 12 January 2017 - Discussion started: 17 January 2017

Revised: 13 April 2017 - Accepted: 26 April 2017 - Published: 17 May 2017

\begin{abstract}
Vertical and horizontal distributions of total dissolved amino acids (TDAAs), dissolved organic carbon (DOC), and dissolved organic nitrogen (DON) were measured in the East/Japan Sea (EJS). The euphotic zone of this sea is N-limited, and the $\mathrm{N}: \mathrm{P}$ ratio is $\sim 13$ below $200 \mathrm{~m}$ depth. Elevated TDAA concentrations $(137 \pm 34 \mathrm{nM})$ and DOC-normalized yields $(0.8 \pm 0.2 \%$ of DOC) were observed in deep waters $(\geq 1000 \mathrm{~m})$ of the EJS and compared with those in the deep North Pacific Ocean. Significantly high TDAA concentrations and yields were observed in a region of deep-water formation, indicating the convection of margin-derived bioavailable dissolved organic matter (DOM) to deep waters. Declining TDAA concentrations $(36 \pm 12 \%)$ and yields $(33 \pm 13 \%)$ were observed between 1000 and $3000 \mathrm{~m}$ throughout the EJS, indicating the utilization of bioavailable DOM in deep waters. Concentrations of the D-enantiomers of amino acids (Ala, Glx, Asx, and Ser) were relatively high in deep waters of the EJS, indicating substantial bacterial contributions to DOM from surface and upper mesopelagic waters. Climate warming during the past few decades in the EJS is weakening deep convection during the winter, and one consequence of this reduction in deep convection is a decline in the supply of bioavailable DOM from surface waters.
\end{abstract}

\section{Introduction}

The East/Japan Sea (EJS) is an enclosed marginal sea in the northwestern Pacific Ocean surrounded by Korea, Japan, and Russia. The EJS consists of three deep basins (>2000 m), including the Ulleung Basin in the southwest, the Yamato Basin in the southeast, and the Japan Basin in the northern region. The Tsushima Current transports warm and saline waters into the EJS through the shallow Korea/Tsushima Strait, which has a sill depth of $\sim 130 \mathrm{~m}$. The Tsushima Current water occurs in the upper $150 \mathrm{~m}$ of the Ulleung Basin and the Yamato Basin, and encounters cold waters formed in the northern part of the polar front at about $40^{\circ} \mathrm{N}$. The deep water $(\geq 1000 \mathrm{~m})$ in the EJS is formed by deep convection and brine rejection (Martin et al., 1992; Kim et al., 2001; Talley et al., 2003; Postlethwaite et al., 2005; Jenkins, 2008). On the basis of salinity and oxygen-isotope budgets, Postlethwaite et al. (2005) estimated the potential rate of bottom-water formation driven by brine rejection (depth $>2500 \mathrm{~m}$ ) to be about $4 \times 10^{12} \mathrm{~m}^{3} \mathrm{yr}^{-1}$, which accounts for $25-35 \%$ of the abyssal water formation. Tracer studies have shown that the turnover time of deep water is on the order of 100 years (Harada and Tsunogai, 1986; Watanabe et al., 1991).

The EJS is a dynamic and productive marginal sea (Jenkins, 2008), with an elevated rate of primary production ( $\sim 200 \mathrm{~g} \mathrm{C} \mathrm{m}^{-2} \mathrm{yr}^{-1}$ ) based on sediment trap data (Hong, 1998). Surface waters in the EJS are strongly N-limited and dominated by cyanobacteria and pelagophytes (Kim et al., 2010). The concentrations of dissolved organic nitrogen 
(DON) $(4-7 \mu \mathrm{M})$ in the upper $100 \mathrm{~m}$ of the EJS are slightly lower than those in major ocean basins due to the apparent uptake of DON by cyanobacteria, as suggested by a strong negative correlation between the concentrations of DON and zeaxanthin, a biomarker of cyanobacteria (Kim and Kim, 2013). Deep waters of the EJS have the highest concentrations $(\sim 58 \mu \mathrm{M})$ of dissolved organic carbon (DOC) measured in the deep ocean (Kim et al., 2015). Elevated concentrations of DOC in deep waters are indicative of the rapid transport of organic matter from surface waters, but relatively little is known about the source, reactivity, and chemical composition of DOM in the EJS.

Amino acids are major biochemical components of plankton biomass (Wakeham et al., 1997; Kaiser and Benner, 2009) and key constituents of marine DOM (Benner, 2002). The abundance and composition of dissolved amino acids can provide insights about ecosystem productivity (Shen et al., 2012, 2017), DOM bioavailability (Davis and Benner, 2007), bacterial contributions to DOM (McCarthy et al., 1998; Kaiser and Benner, 2008), and the extent of alteration of organic matter (Cowie and Hedges, 1994; Dauwe and Middelburg, 1998). In the present study, we determined the compositions, including D- and L-enantiomers, and concentrations of total dissolved amino acids (TDAAs) in the EJS on a basin-wide scale to further evaluate the dynamics of DOC and DON in the EJS.

\section{Materials and methods}

Seawater samples were collected during two periods: (A) 918 July 2009, aboard the R/V M.A. Lavrentyev of the Pacific Oceanological Institute (POI), Russia, and (B) 8-18 August 2009, aboard the R/V Tam-Yang of Pukyong National University (PKNU), Korea (Fig. 1). Seawater samples were filtered on board through a syringe glass-fiber filter (Whatman, $0.7 \mu \mathrm{m}$ pore size, $25 \mathrm{~mm}$ ) for DOC, TDAAs, TDN (total dissolved nitrogen), and DIN (dissolved inorganic nitrogen; $\mathrm{NO}_{3}^{-}+\mathrm{NO}_{2}^{-}+\mathrm{NH}_{4}^{+}$). Water samples for $\mathrm{DOC}$ and TDN measurements were acidified with $6 \mathrm{~mol} \mathrm{~L}^{-1} \mathrm{HCl}$ to $\mathrm{pH} \sim 2$ in pre-combusted glass ampoules $\left(550^{\circ} \mathrm{C}\right.$ for $5 \mathrm{~h}$ ) and stored at $4{ }^{\circ} \mathrm{C}$ for preservation until analysis. Samples for DIN and TDAA analyses were collected in polyethylene bottles and stored frozen $\left(-20^{\circ} \mathrm{C}\right)$ until analysis. Sample handling and preparations were performed in a clean bench (class 100). In the laboratory, the concentrations of DIN were measured using an auto-analyzer (Futura Plus, Alliance Co.) based on colorimetric analysis. The concentrations of DOC and TDN were measured using a TOC- $\mathrm{V}_{\mathrm{CPH}}$ analyzer (Shimadzu, Japan) based on high-temperature combustion. The reliability of the measurements was verified on a daily basis by analysis of DIN and DOC certified seawater samples (MOOS-1: $23.7 \pm 0.9 \mu \mathrm{M}$ for DIN, National Research Council; DSR: $44-46 \mu \mathrm{M}$ for DOC, University of Miami). The re-

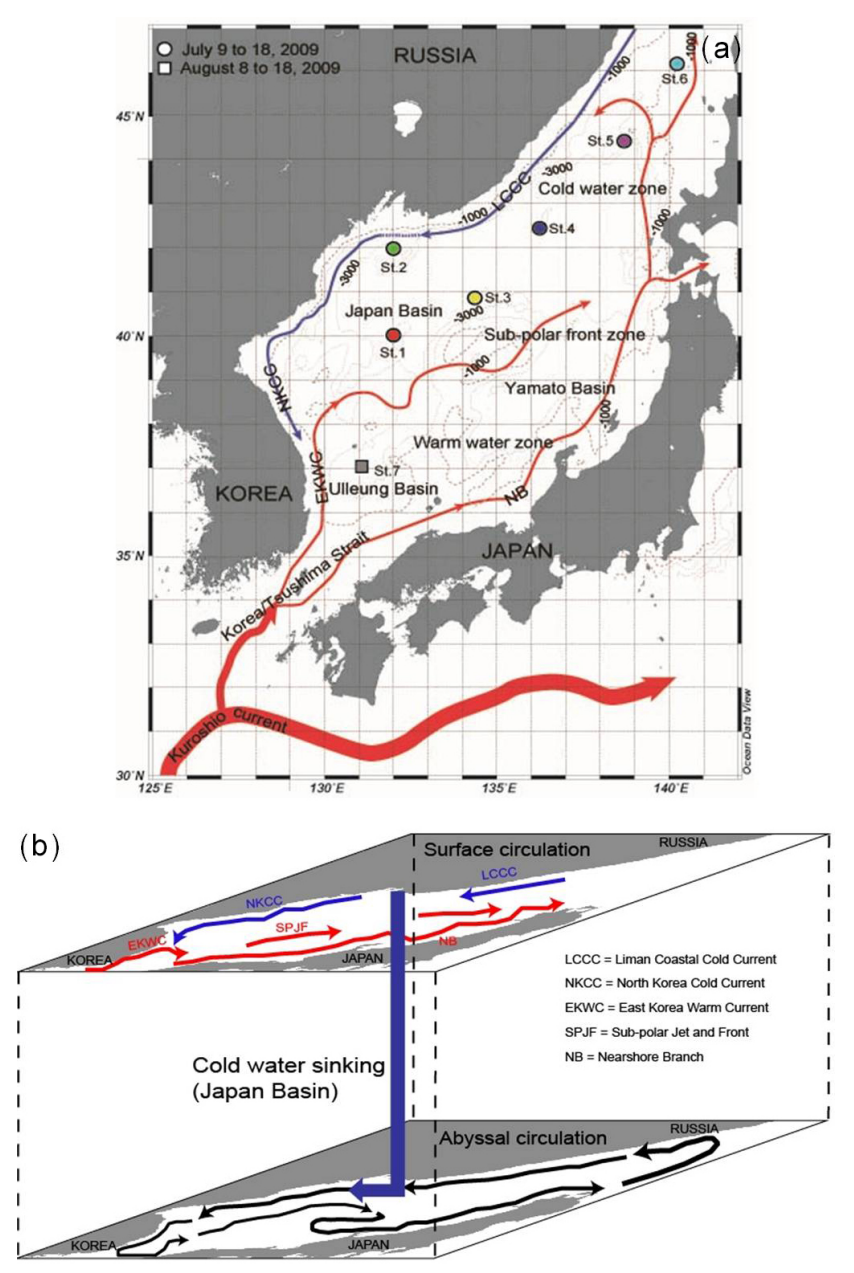

Figure 1. (a) A map of the region showing stations (St.) in the East/Japan Sea. (b) A schematic of the water circulations of the surface and bottom waters in the East/Japan Sea (Senjyu et al., 2005).

sults were in good agreement with certified DSR values (deviation: $<5 \%)$.

Filtered $(0.7 \mu \mathrm{m})$ water samples were subjected to acid hydrolysis for determination of TDAA concentration and composition. The TDAA concentrations, including both free amino acids and combined amino acids, were measured using high-performance liquid chromatography (Agilent 1260 with fluorescence detector). Water samples $(100 \mu \mathrm{L})$ were dried under nitrogen gas and were subjected to vapor-phase hydrolysis with $6 \mathrm{~mol} \mathrm{~L}^{-1} \mathrm{HCl}$ at $150{ }^{\circ} \mathrm{C}$ for $32.5 \mathrm{~min}$ in a CEM Mars 5000 microwave (Kaiser and Benner, 2005). The D- and L-enantiomers of amino acids were derivatized with $o$-phthaldialdehyde and $N$-isobutyryl-L-cysteine (IBLC), and they were separated on a Poroshell 120 ECC18 column $(4.6 \times 100 \mathrm{~mm}, 2.7 \mu \mathrm{m}$ particles) (Shen et al., 2017). Acid-catalyzed racemization of enantiomers during hydrolysis was corrected according to Kaiser and Benner (2005). Eighteen amino acids were included in the analysis: asparagine + aspartic acid (Asx), glutamine + glutamic 


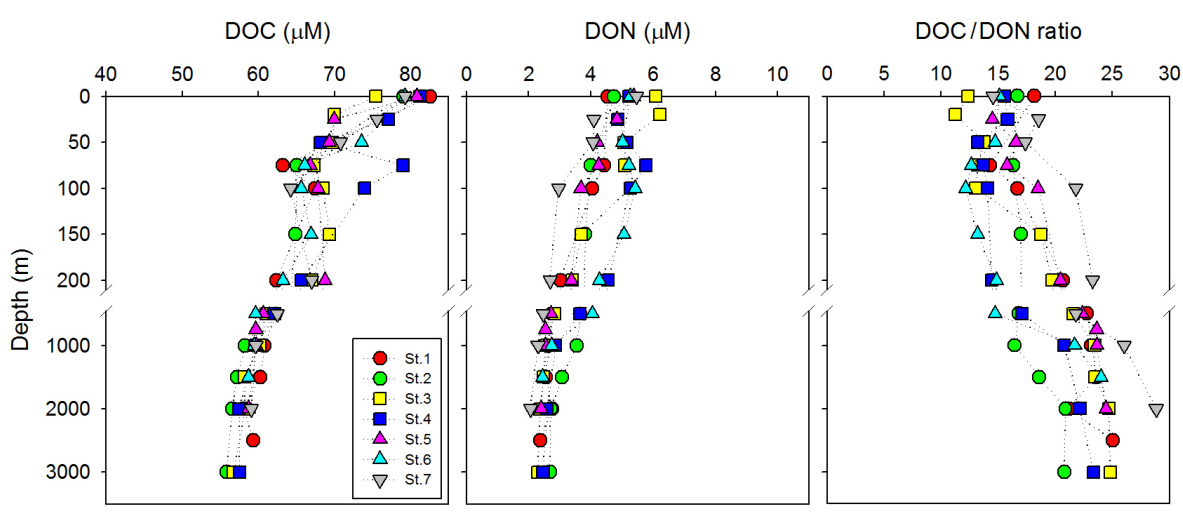

Figure 2. Vertical profiles of dissolved organic carbon (DOC), dissolved organic nitrogen (DON), and the DOC : DON ratio in the East/Japan Sea.

acid (Glx), serine (Ser), histidine (His), glycine (Gly), threonine (Thr), $\beta$-alanine ( $\beta$-Ala), arginine (Arg), alanine (Ala), $\gamma$-aminobutyric acid ( $\gamma$-Aba), tyrosine (Tyr), valine (Val), phenylalanine (Phe), isoleucine (Ile), leucine (Leu), and lysine (Lys). The four abundant D-amino acids (D-Asx, D-Glx, D-Ser, and D-Ala) are reported in this study. The DOC- and DON-normalized yields of TDAAs were expressed as a percentage of the total DOC and DON. The DOC- and DONnormalized yields of TDAAs were calculated as TDAAs $(\%$ DOC $)$ or TDAAs $(\%$ DON $)=\frac{\text { TDAA-C or TDAA-N }}{\text { DOC orDON }} \times 100$, where the denominator and numerator represent concentrations of total DOC or DON and the DOC or DON comprised by TDAAs, respectively. The two non-protein amino acids $(\beta$-Ala and $\gamma$-Aba) were not included in the yield calculation (Cowie and Hedges, 1994).

The concentrations of DON were determined indirectly by subtracting the concentrations of DIN (nitrate + nitrite + ammonium) from concentrations of TDN. This calculation can produce large uncertainties when the total concentrations of dissolved nutrients are similar to those of dissolved inorganic nutrients. However, the average concentrations of TDN in surface and deep waters (15.6 \pm 5.8 and $26.6 \pm 2.4 \mu \mathrm{M}$ ) were much higher than those of DIN $(10.8 \pm 6.3$ and $23.7 \pm 2.6 \mu \mathrm{M})$, thus allowing a reasonable comparison of the overall depth trends of DON. Most values are expressed as the mean \pm standard deviation (SD) in this study.

\section{Results and discussion}

\subsection{Concentrations and distributions of DOM and TDAAs in the EJS}

The concentrations of DOC and DON ranged from 57 to 83 and 2.0 to $8.4 \mu \mathrm{M}$, respectively, in the EJS (Table 1; Fig. 2). The average DOC and DON concentrations were $72 \pm 6$ and $4.8 \pm 0.8 \mu \mathrm{M}$ in surface waters $(0-200 \mathrm{~m})$ and $59 \pm 1$ and $2.6 \pm 0.3 \mu \mathrm{M}$ in deep waters $(\geq 1000 \mathrm{~m})$, respectively. The concentrations of DOC and DON in deep waters were approximately 18 and $54 \%$ lower than those in surface waters, indicating the preferential remineralization of DON in deep waters. Deep-water concentrations of DOC in the EJS were higher than those in the major oceans $(34-48 \mu \mathrm{M})$ (Bauer et al., 1992; Sharp et al., 1995; Thomas et al., 1995; Hansell and Carlson, 1998). Kim et al. (2015) suggested the high concentrations of DOC in deep waters of the EJS are due to low rates of degradation $\left(0.04 \mu \mathrm{mol} \mathrm{Ckg}^{-1} \mathrm{yr}^{-1}\right)$ associated with low water temperatures $\left(<1^{\circ} \mathrm{C}\right)$.

The concentrations of DON in surface waters of the EJS were similar to those in the global surface ocean $(4.4 \pm 0.5 \mu \mathrm{M})$ (Letscher et al., 2013). Unlike DOC, the concentrations of DON in deep waters of the EJS were similar to values in the eastern Pacific $(2.5 \pm 0.4 \mu \mathrm{M})$ and slightly lower than those in the Southern Ocean $(3.5 \pm 0.6 \mu \mathrm{M})$, the North Atlantic $(3.2 \pm 0.3 \mu \mathrm{M})$, and the Mediterranean Sea $(3.5 \pm 0.4 \mu \mathrm{M})$ (Loh and Bauer, 2000; Hansell and Carlson, 2001; Pujo-Pay et al., 2011). The DOC: DON ratios in deep waters of the EJS $(23 \pm 3)$ were higher than those in the North Pacific, North Atlantic, and Mediterranean Sea (Loh and Bauer, 2000; Hansell and Carlson, 2001; Pujo-Pay et al., 2011) (Fig. 2).

Kim and Kim (2013) found the DOC: DON ratios in the surface EJS were similar to those in the North Pacific Ocean, which is N-limited (Zehr et al., 2001). In the EJS cyanobacteria dominate $(20-65 \%)$ the phytoplankton community in the surface mixed layer, where DIN:DIP (dissolved inorganic phosphate) ratios were $<5$ (Kim et al., 2010). Significant negative correlations between zeaxanthin concentrations and DON concentrations have been observed in the surface mixed layer of the EJS, indicating that $\mathrm{C}: \mathrm{N}$ stoichiometry of DOM can be strongly influenced by phytoplankton (Kim and Kim, 2013).

The concentrations of TDAAs ranged from 87 to $290 \mathrm{nM}$ in the EJS (Table 1; Fig. 2). The average TDAA concentrations decreased by $\sim 37 \%$ from $248 \pm 27 \mathrm{nM}$ in surface waters to $137 \pm 34 \mathrm{nM}$ in deep waters (Fig. 3). The concen- 
Table 1. Physicochemical characteristics in the East/Japan Sea.

\begin{tabular}{|c|c|c|c|c|c|c|c|c|c|c|}
\hline Station & $\begin{array}{l}\text { Depth } \\
\text { (m) }\end{array}$ & $\begin{array}{l}\text { Temp. } \\
\left({ }^{\circ} \mathrm{C}\right)\end{array}$ & $\begin{array}{l}\text { Sal. } \\
\text { (psu) }\end{array}$ & $\begin{array}{l}\text { DOC } \\
(\mu \mathrm{M})\end{array}$ & $\begin{array}{l}\text { DON } \\
(\mu \mathrm{M})\end{array}$ & $\begin{array}{l}\text { TDAAs } \\
(\mathrm{nM})\end{array}$ & $\begin{array}{l}\text { TDAAs } \\
(\% \text { DOC })\end{array}$ & DI & $\begin{array}{l}\beta \text {-Ala } \\
(\operatorname{mol} \%)\end{array}$ & $\begin{array}{l}\gamma \text {-Aba } \\
(\operatorname{mol} \%)\end{array}$ \\
\hline \multirow[t]{9}{*}{1} & 0 & 21.079 & 33.734 & 83 & 4.5 & 290 & 1.2 & -0.87 & 3 & 1 \\
\hline & 75 & 10.481 & 34.164 & 63 & 4.4 & 263 & 1.5 & -0.24 & 3 & 1 \\
\hline & 100 & 10.323 & 34.177 & 67 & 4.0 & 234 & 1.4 & 0.70 & 1 & 0 \\
\hline & 200 & 8.688 & 34.188 & 62 & 3.0 & 203 & 1.1 & -0.78 & 5 & 1 \\
\hline & 500 & 0.764 & 34.060 & 62 & 2.7 & 181 & 0.9 & -1.44 & 9 & 2 \\
\hline & 1000 & 0.264 & 34.064 & 61 & 2.6 & 170 & 0.9 & -1.06 & 5 & 2 \\
\hline & 1500 & 0.154 & 34.064 & 60 & 2.6 & 132 & 0.8 & -0.07 & 5 & 1 \\
\hline & 2000 & 0.102 & 34.064 & 58 & 2.7 & 96 & 0.6 & 0.70 & 4 & 1 \\
\hline & 2500 & 0.086 & 34.065 & 59 & 2.4 & 90 & 0.5 & -0.38 & 4 & 2 \\
\hline \multirow[t]{8}{*}{2} & 0 & 21.079 & 33.734 & 79 & 4.7 & 285 & 1.2 & -1.19 & 6 & 1 \\
\hline & 75 & 10.481 & 34.164 & 65 & 4.0 & 272 & 1.2 & -2.33 & 8 & 1 \\
\hline & 150 & 10.323 & 34.177 & 65 & 3.8 & 248 & 1.3 & -1.16 & 5 & 1 \\
\hline & 500 & 8.688 & 34.188 & 61 & 3.7 & 224 & 1.3 & -0.52 & 5 & 2 \\
\hline & 1000 & 0.764 & 34.060 & 58 & 3.5 & 214 & 1.3 & -0.28 & 3 & 1 \\
\hline & 1500 & 0.264 & 34.064 & 57 & 3.1 & 202 & 1.2 & -1.00 & 6 & 2 \\
\hline & 2000 & 0.154 & 34.064 & 57 & 2.7 & 146 & 0.9 & -0.82 & 4 & 1 \\
\hline & 3000 & 0.102 & 34.064 & 56 & 2.7 & 95 & 0.6 & 0.05 & 5 & 1 \\
\hline \multirow[t]{12}{*}{3} & 0 & 18.044 & 33.814 & 75 & 6.1 & 277 & 1.3 & -0.30 & 3 & 1 \\
\hline & 20 & 6.882 & 34.061 & 70 & 6.2 & 275 & 1.3 & -1.24 & 6 & 2 \\
\hline & 50 & 4.199 & 34.072 & 70 & 5.1 & 262 & 1.3 & -1.10 & 5 & 1 \\
\hline & 75 & 3.430 & 34.075 & 67 & 5.1 & 252 & 1.2 & -1.49 & 5 & 3 \\
\hline & 100 & 3.187 & 34.072 & 69 & 5.3 & 250 & 1.4 & -0.21 & 4 & 1 \\
\hline & 150 & 2.666 & 34.063 & 69 & 3.7 & 208 & 1.0 & -1.17 & 6 & 2 \\
\hline & 200 & 2.071 & 34.059 & 67 & 3.4 & 188 & 0.9 & -1.38 & 5 & 1 \\
\hline & 500 & 0.949 & 34.070 & 61 & 2.8 & 159 & 0.8 & -1.45 & 6 & 2 \\
\hline & 1000 & 0.390 & 34.068 & 60 & 2.6 & 155 & 0.8 & -2.02 & 8 & 3 \\
\hline & 1500 & 0.186 & 34.065 & 58 & 2.5 & 153 & 0.8 & -1.03 & 7 & 2 \\
\hline & 2000 & 0.115 & 34.065 & 57 & 2.4 & 135 & 0.7 & -1.62 & 7 & 2 \\
\hline & 3000 & 0.082 & 34.066 & 57 & 2.3 & 105 & 0.6 & -0.73 & 6 & 1 \\
\hline \multirow[t]{10}{*}{4} & 0 & 15.841 & 33.599 & 81 & 5.2 & 276 & 1.1 & -1.36 & 5 & 1 \\
\hline & 25 & 5.904 & 34.013 & 77 & 4.9 & 246 & 1.0 & -2.03 & 8 & 2 \\
\hline & 50 & 3.533 & 34.087 & 68 & 5.2 & 229 & 1.1 & -1.62 & 5 & 2 \\
\hline & 75 & 2.458 & 34.087 & 79 & 5.8 & 231 & 1.0 & -0.65 & 6 & 1 \\
\hline & 100 & 2.089 & 34.086 & 74 & 5.3 & 191 & 0.8 & -2.00 & 7 & 2 \\
\hline & 200 & 1.252 & 34.068 & 66 & 4.6 & 177 & 0.9 & -1.35 & 6 & 1 \\
\hline & 500 & 0.617 & 34.068 & 62 & 3.6 & 171 & 0.9 & -1.18 & 7 & 2 \\
\hline & 1000 & 0.258 & 34.066 & 60 & 2.9 & 152 & 0.9 & 0.02 & 4 & 1 \\
\hline & 2000 & 0.100 & 34.065 & 57 & 2.6 & 130 & 0.8 & -0.30 & 6 & 1 \\
\hline & 3000 & 0.081 & 34.066 & 57 & 2.5 & 113 & 0.7 & 0.12 & 4 & 1 \\
\hline \multirow[t]{10}{*}{5} & 0 & 14.574 & 33.574 & 81 & 5.4 & 278 & 1.2 & -0.46 & 3 & 1 \\
\hline & 25 & 3.625 & 34.069 & 70 & 4.8 & 250 & 1.2 & -1.26 & 4 & 1 \\
\hline & 50 & 2.238 & 34.080 & 69 & 4.2 & 243 & 1.2 & -0.72 & 4 & 1 \\
\hline & 75 & 1.705 & 34.067 & 67 & 4.2 & 233 & 1.3 & 0.03 & 2 & 0 \\
\hline & 100 & 1.320 & 34.066 & 68 & 3.7 & 200 & 1.1 & 0.23 & 5 & 1 \\
\hline & 200 & 0.881 & 34.065 & 69 & 3.4 & 171 & 0.8 & -0.73 & 6 & 1 \\
\hline & 500 & 0.507 & 34.066 & 61 & 2.7 & 169 & 1.0 & -0.81 & 5 & 1 \\
\hline & 750 & 0.320 & 34.066 & 60 & 2.5 & 169 & 1.0 & -0.77 & 5 & 1 \\
\hline & 1000 & 0.219 & 34.065 & 60 & 2.5 & 164 & 1.0 & -0.56 & 5 & 1 \\
\hline & 2000 & 0.106 & 34.065 & 59 & 2.4 & 123 & 0.6 & -1.85 & 8 & 3 \\
\hline
\end{tabular}


Table 1. Continued.

\begin{tabular}{rrrrrrrrrrr}
\hline Station & $\begin{array}{r}\text { Depth } \\
(\mathrm{m})\end{array}$ & $\begin{array}{r}\text { Temp. } \\
\left({ }^{\circ} \mathrm{C}\right)\end{array}$ & $\begin{array}{c}\text { Sal. } \\
(\mathrm{psu})\end{array}$ & $\begin{array}{r}\text { DOC } \\
(\mu \mathrm{M})\end{array}$ & $\begin{array}{r}\text { DON } \\
(\mu \mathrm{M})\end{array}$ & $\begin{array}{r}\text { TDAAs } \\
(\mathrm{nM})\end{array}$ & $\begin{array}{c}\text { TDAAs } \\
(\% \text { DOC })\end{array}$ & $\begin{array}{l}\beta \text {-Ala } \\
(\mathrm{mol} \%)\end{array}$ & $\begin{array}{l}\gamma \text {-Aba } \\
(\mathrm{mol} \%)\end{array}$ \\
\hline 6 & 0 & 12.608 & 33.498 & 79 & 5.3 & 286 & 1.2 & -0.73 & 6 & 1 \\
& 50 & 3.218 & 34.085 & 74 & 5.0 & 283 & 1.4 & -1.34 & 3 & 1 \\
& 75 & 2.227 & 34.076 & 66 & 5.2 & 241 & 1.2 & -0.36 & 7 & 1 \\
& 100 & 1.887 & 34.070 & 66 & 5.4 & 231 & 1.3 & -1.35 & 3 & 1 \\
& 150 & 1.505 & 34.075 & 67 & 5.1 & 225 & 1.1 & 0.10 & 5 & 3 \\
& 200 & 1.305 & 34.080 & 63 & 4.3 & 213 & 1.2 & -0.76 & 4 & 1 \\
& 500 & 0.568 & 34.067 & 60 & 4.0 & 212 & 1.3 & -0.71 & 4 & 1 \\
& 1000 & 0.233 & 34.065 & 59 & 2.7 & 149 & 0.8 & -0.07 & 6 & 1 \\
& 1500 & 0.137 & 34.065 & 59 & 2.4 & 141 & 0.9 & -0.01 & 5 & 1 \\
\hline 7 & 0 & 22.545 & 33.705 & 79 & 5.4 & 254 & 1.0 & -1.58 & 6 & 2 \\
& 25 & 20.677 & 33.810 & 76 & 4.1 & 241 & 1.0 & -1.92 & 6 & 2 \\
& 50 & 17.306 & 34.241 & 71 & 4.1 & 232 & 1.2 & -0.02 & 4 & 1 \\
& 100 & 14.636 & 34.151 & 64 & 2.9 & 209 & 1.1 & -1.07 & 5 & 1 \\
& 200 & 1.989 & 34.050 & 67 & 2.9 & 185 & 0.9 & -1.23 & 7 & 1 \\
& 500 & 0.532 & 34.065 & 62 & 2.9 & 163 & 0.9 & -0.35 & 5 & 1 \\
& 1000 & 0.242 & 34.064 & 60 & 2.3 & 127 & 0.7 & -1.07 & 6 & 1 \\
& 2000 & 0.097 & 34.065 & 59 & 2.0 & 87 & 0.5 & 0.10 & 5 & 2 \\
\hline
\end{tabular}

trations of TDAAs in the EJS were in general higher than those at the Bermuda Atlantic Time-series Study (BATS) site (150-198 nM in surface waters; $87-103 \mathrm{nM}$ in deep waters) and the Hawaii Ocean Time-series (HOT) site (190-285 nM in surface waters; $45-70 \mathrm{nM}$ in deep waters) (Fig. 4; Kaiser and Benner, 2008, 2009).

There is no notable DOC anomaly in the EJS that would indicate significant lateral inputs from rivers or other sources (Kim et al., 2015). This is consistent with the fact that there are no major rivers that drain into the EJS, which is fed exclusively by the Pacific Ocean. Abyssal circulation in the EJS has relatively strong cyclonic flows along the basin periphery and sluggish flows in the interior region (Fig. 1; Senjyu et al., 2005). The lowest concentration of DOC was found in the southern area of the EJS along the abyssal circulation, with a similar trend of AOU (apparent oxygen utilization) (Kim et al., 2015). The lowest concentration of TDAAs $(87 \mathrm{nM})$ was found at $2000 \mathrm{~m}$ depth in the southern frontal zone (station 7). This station is located in the central Ulleung Basin, which may have the oldest water among the sampling sites. The deep water in the Ulleung Basin is known to originate from the northern Japan Basin (Kim et al., 1991; Senjyu et al., 2005).

\subsection{Bioavailable DOM in the EJS}

The amino acid components of DOM comprise an important fraction of the bioavailable DOM in seawater, and the DOCnormalized yield of TDAAs (\% DOC) is a useful proxy of bioavailable DOM (Davis and Benner, 2007). Bioassay experiments have demonstrated that TDAA DOC yields decline with increasing biodegradation over time and are indicative of TDAA reactivity (Davis and Benner, 2007; Davis et al., 2009). In addition, the global ocean distribution of TDAA yields is consistent with bioassay observations (Kaiser and Benner, 2009). TDAAs accounted for 0.5 to $1.5 \%$ of the DOC and 4.1 to $9.1 \%$ of the DON in the EJS (Fig. 3). TDAA yields were $1.2 \pm 0.1 \%$ of the DOC and $6.7 \pm 1.2 \%$ of the DON in surface waters, and $0.8 \pm 0.2 \%$ of the DOC and $6.4 \pm 1.1 \%$ of the DON in deep waters (Table 1). DOCnormalized yields of TDAAs (\% DOC) between the surface waters and deep waters showed a significant difference $(p<0.05)$; however, DON-normalized yields of TDAAs ( $\%$ DON) presented no significant difference $(p=0.41)$. The yields of amino acids (\% DOC) decreased from surface to deep waters (Fig. 3), indicating the components of DOM containing amino acids were more bioavailable than bulk DOC. The average yields of TDAAs in deep waters of the EJS were similar to those $(0.7 \pm 0.1 \%$ DOC $)$ at the BATS site and were greater than those $(0.5 \pm 0.1 \%$ DOC $)$ at the HOT site (Kaiser and Benner, 2009), indicating the occurrence of some bioavailable DOM in EJS and BATS deep waters (Fig. 4).

Yields (\% DOC) of TDAAs decreased by $33 \pm 13 \%$ in deep waters $(1000-3000 \mathrm{~m})$. The declines in TDAA yields (\% DOC) in the EJS were greater than those at BATS (25\%) and HOT (17\%) (Kaiser and Benner, 2009), indicating the occurrence of bioavailable DOM and a greater reactivity of TDAAs in deep waters of the EJS. The yields of TDAAs in bottom waters of the EJS were below $0.7 \%$ DOC, indicating the refractory nature of DOM in bottom waters with ventilation ages of $\sim 100$ years (Harada and Tsunogai, 1986; Watanabe et al., 1991). 


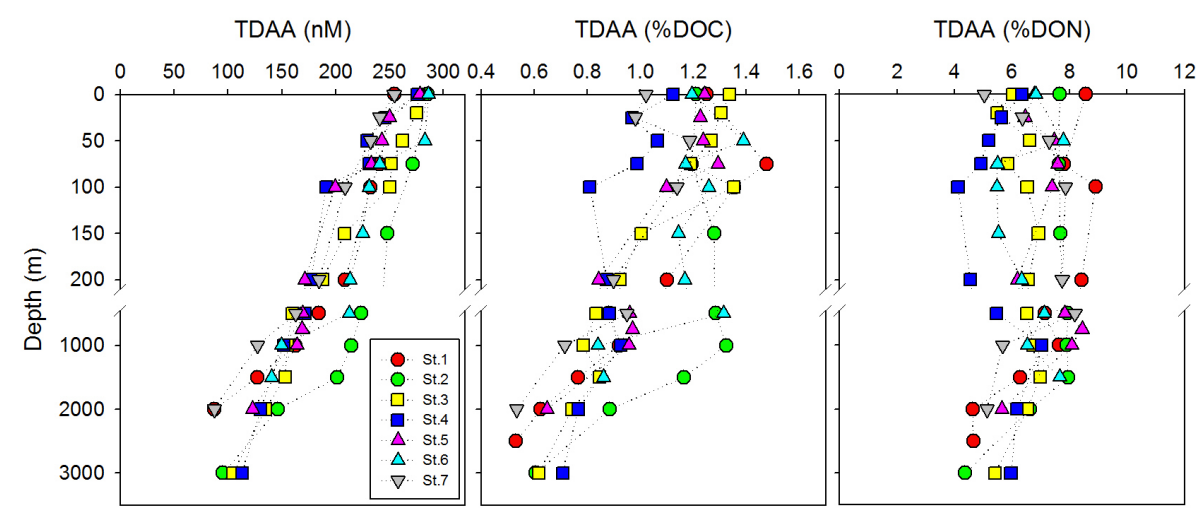

Figure 3. Vertical profiles of total dissolved amino acids (TDAAs), DOC-normalized yields of TDAAs (\% DOC), and DON-normalized yields of TDAAs (\% DON) in the East/Japan Sea.
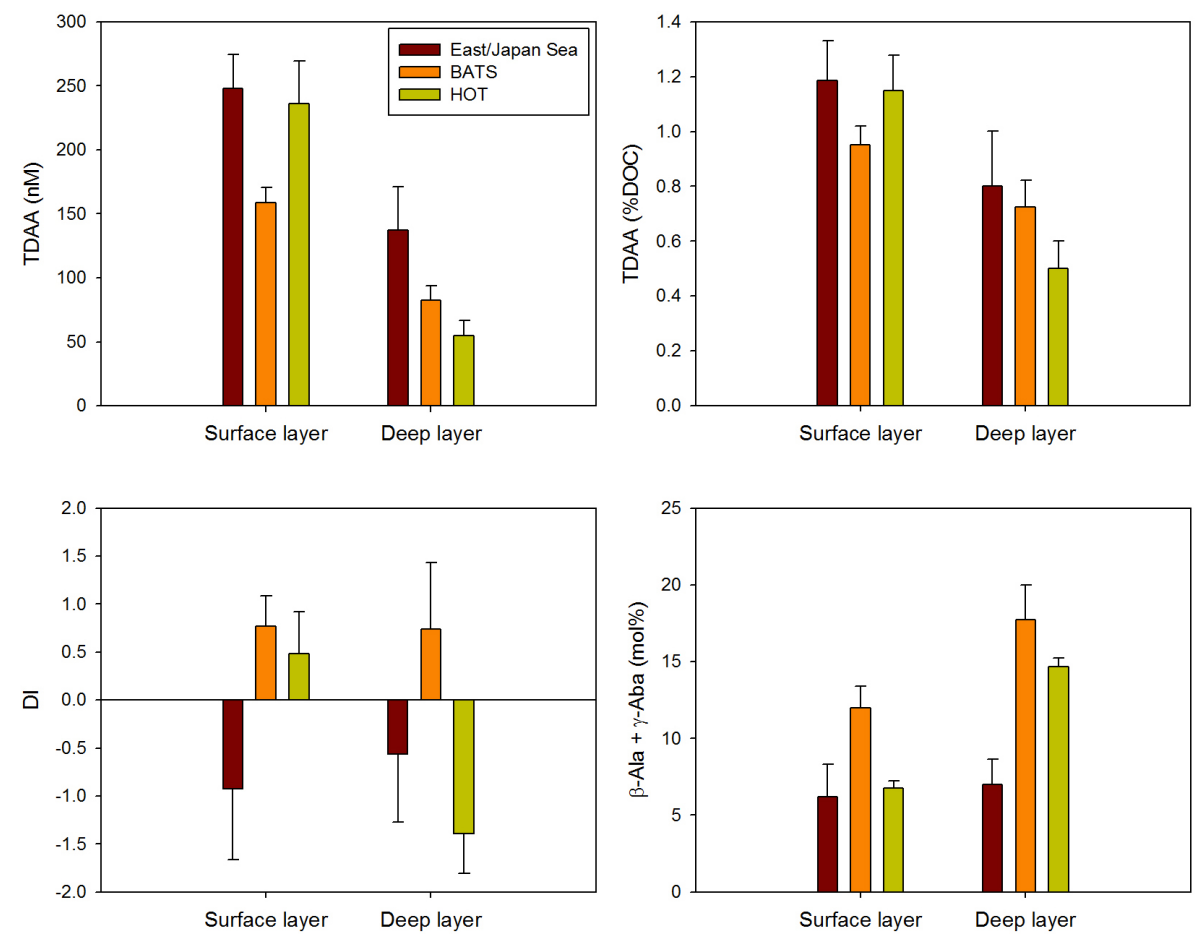

Figure 4. Average total dissolved amino acid (TDAA) concentrations, DOC-normalized yields of TDAAs (\% DOC), degradation index, and mole percentage (mol \%) of $\beta$-Ala $+\gamma$-Aba from surface $(0-200 \mathrm{~m})$ and deep $(\geq 1000 \mathrm{~m}$ ) layers in the East/Japan Sea, BATS, and HOT. Error bars represent standard deviations.

There was considerable spatial variability in TDAA yields (\% DOC) and bioavailable DOM among stations in the EJS (Fig. 3). This variability was particularly evident in deep waters at station 2 , which had very high TDAA yields (1.3 and $1.2 \% \mathrm{DOC}$ ) at 1000 and $1500 \mathrm{~m}$, indicating the presence of bioavailable DOM with a semi-labile nature (Davis and Benner, 2007). These high yields at depth are consistent with deep-water convection in this region of the EJS and the potential input of DOM from nearby margin surface waters (Kim et al., 2002; Talley et al., 2003). In contrast, the low TDAA yield $(0.6 \%$ DOC) at $3000 \mathrm{~m}$ was indicative of
DOM with a refractory nature (Davis and Benner, 2007). Deep convection in the EJS appears to have weakened in recent decades in response to climate change (Gamo, 2011), and the low TDAA yields and refractory nature of DOM in abyssal waters $(\geq 2500 \mathrm{~m})$ are consistent with longer residence times and a greater extent of microbial decomposition. 


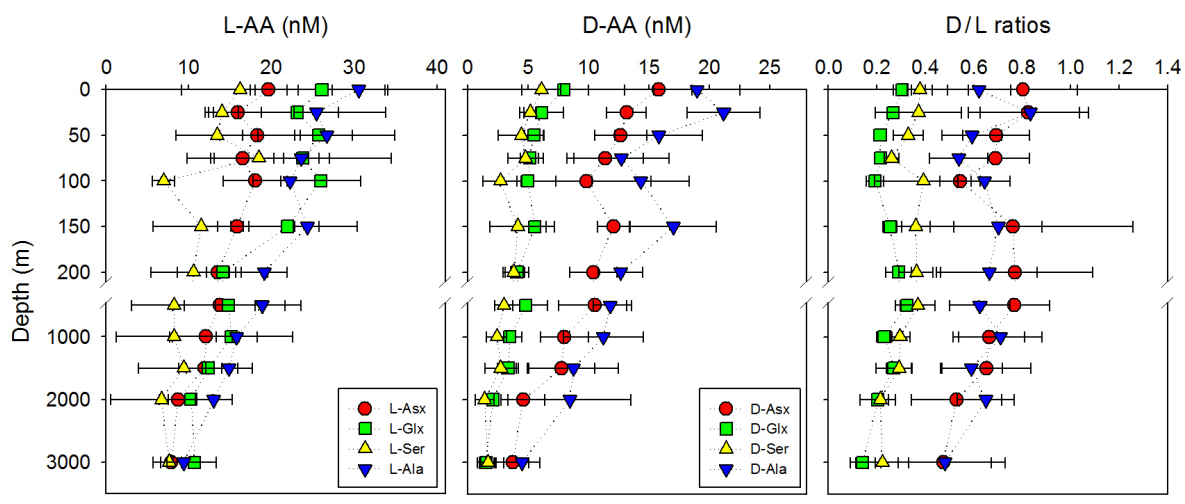

Figure 5. Average concentrations of total hydrolyzable L- and D-enantiomers of asparagine + aspartic acid (Asx), glutamine + glutamic acid (Glx), serine (Ser), and alanine (Ala) concentrations in the EJS, and the average D : L ratios for these amino acids.

Table 2. Average concentrations of D- and L-enantiomers of aspartic acid and asparagines (D- and L-Asx), glutamic acid and glutamine (Dand L-Glx), serine (D- and L-Ser), and alanine (D- and L-Ala) and the enantiomeric D : L ratios.

\begin{tabular}{|c|c|c|c|c|c|c|c|c|c|c|c|c|}
\hline \multirow{2}{*}{$\begin{array}{l}\text { Depth } \\
\text { (m) }\end{array}$} & D-Asx & L-Asx & D-Glx & L-Glx & D-Ser & L-Ser & D-Ala & L-Ala & \multirow[t]{2}{*}{ D : L-Asx } & \multirow[t]{2}{*}{ D : L-Glx } & \multirow[t]{2}{*}{ D : L-Ser } & \multirow[t]{2}{*}{ D : L-Ala } \\
\hline & \multicolumn{8}{|c|}{$(\mathrm{nM})$} & & & & \\
\hline 0 & 16 & 20 & 8 & 26 & 6 & 16 & 19 & 31 & 0.80 & 0.31 & 0.38 & 0.62 \\
\hline 25 & 13 & 16 & 6 & 23 & 5 & 14 & 21 & 25 & 0.83 & 0.27 & 0.37 & 0.83 \\
\hline 50 & 13 & 18 & 5 & 26 & 4 & 13 & 16 & 27 & 0.69 & 0.21 & 0.33 & 0.59 \\
\hline 75 & 11 & 16 & 5 & 24 & 5 & 18 & 13 & 24 & 0.69 & 0.22 & 0.26 & 0.54 \\
\hline 100 & 10 & 18 & 5 & 26 & 3 & 7 & 14 & 22 & 0.54 & 0.19 & 0.39 & 0.64 \\
\hline 150 & 12 & 16 & 6 & 22 & 4 & 11 & 17 & 24 & 0.76 & 0.25 & 0.36 & 0.70 \\
\hline 200 & 10 & 14 & 4 & 14 & 4 & 11 & 13 & 19 & 0.77 & 0.29 & 0.36 & 0.66 \\
\hline 500 & 11 & 14 & 5 & 15 & 3 & 8 & 12 & 19 & 0.77 & 0.32 & 0.37 & 0.63 \\
\hline 1000 & 8 & 12 & 4 & 15 & 2 & 8 & 11 & 16 & 0.66 & 0.23 & 0.30 & 0.71 \\
\hline 1500 & 8 & 12 & 3 & 12 & 3 & 9 & 9 & 15 & 0.65 & 0.27 & 0.29 & 0.59 \\
\hline 2000 & 5 & 9 & 2 & 10 & 1 & 7 & 8 & 13 & 0.53 & 0.20 & 0.21 & 0.65 \\
\hline 3000 & 4 & 8 & 2 & 11 & 2 & 8 & 5 & 9 & 0.47 & 0.14 & 0.22 & 0.48 \\
\hline
\end{tabular}

\subsection{Amino acid degradation index and non-protein amino acids in the EJS}

The amino acid degradation index (DI), which is based on the composition of protein amino acids, and the mole percentages $(\mathrm{mol} \%)$ of the non-protein amino acids $(\beta$-Ala $+\gamma$ Aba) have been used as indicators of biogeochemical alterations of DOM (Davis et al., 2009). The DI values ranged from -2.33 to 0.70 in the EJS, with more negative values indicating a greater extent of alteration (Table 1). The average DI values in the EJS were $-0.93 \pm 0.74$ in surface water and $-0.72 \pm 0.62$ in deep water. The DI values decreased with depth at the BATS and HOT sites (Kaiser and Benner, 2009), whereas those in the EJS were more variable. The average DI values in the EJS deep waters were intermediate between those $(-1.40 \pm 0.41)$ at HOT and those $(0.74 \pm 0.69)$ at BATS (Kaiser and Benner, 2009) (Fig. 4).

The mole percentages of $\beta$-Ala and $\gamma$-Aba ranged from 1 to 9 and 0 to $3 \mathrm{~mol} \%$, respectively, in the EJS (Table 1). The average $\beta$-Ala and $\gamma$-Aba mole percentages were $5 \pm 1$ and
$1 \pm 1 \mathrm{~mol} \%$ in surface waters and $5 \pm 1$ and $2 \pm 1 \mathrm{~mol} \%$ in deep waters, respectively. The average $\beta$-Ala $+\gamma$-Aba mole percentages in surface waters were similar $( \pm 10 \%)$ to those in the deep water (Fig. 4). The mole percentages of $\beta$-Ala $+\gamma$-Aba in surface and deep waters of the EJS were lower than those at BATS and HOT (Kaiser and Benner, 2009). The mole percentages of $\beta$-Ala in the EJS were similar to those at BATS and HOT, while the mole percentages of $\gamma$ Aba were lower than those at BATS and HOT (Kaiser and Benner, 2009) (Fig. 4).

The mole percentages of $\beta$-Ala $+\gamma$-Aba increased with depth at the HOT site (Kaiser and Benner, 2009), while those in the EJS were variable with depth, as was observed with the DI. In this study, there is a significant, but weak, correlation $(r=0.134, n=66)$ between the amino acid yield $(\%$ DOC) and the DI. Similar observations were made in the western Arctic Ocean (Shen et al., 2012). The DI was negatively correlated $(r=-0.625, n=66)$ with the mole percentages of $\beta$-Ala $+\gamma$-Aba in the EJS. Variable DI values in the Chukchi and Beaufort seas appeared to be associated with 

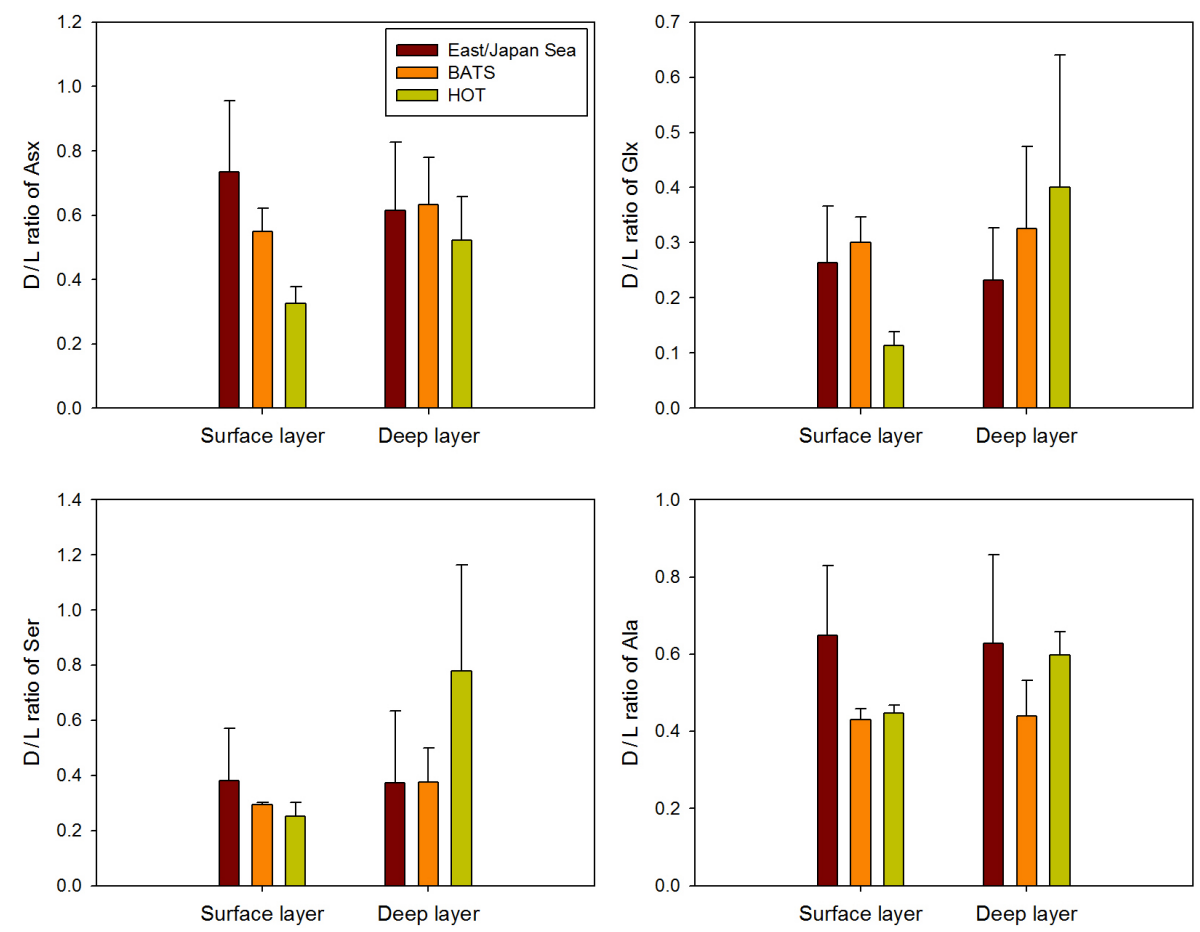

Figure 6. Average D : L ratios of asparagine + aspartic acid (Asx), glutamine + glutamic acid (Glx), serine (Ser), and alanine (Ala) from surface $(0-200 \mathrm{~m})$ and deep ( $\geq 1000 \mathrm{~m}$ ) layers in the East/Japan Sea, BATS, and HOT. Error bars represent standard deviations.

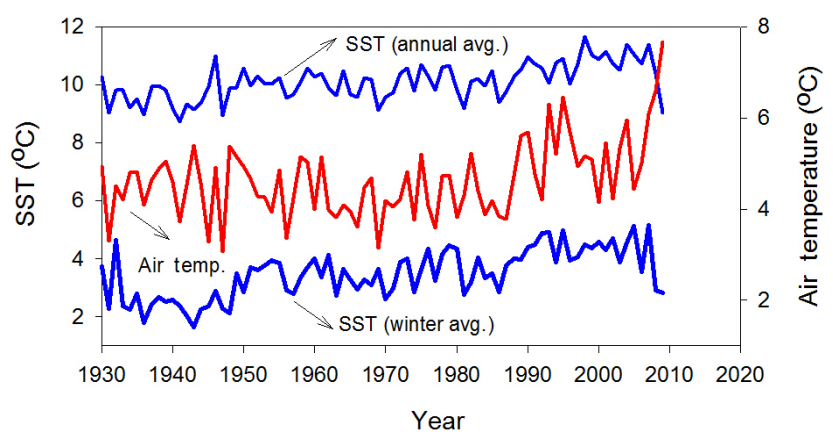

Figure 7. The variability of annual mean air temperature near Vladivostok (red line), and the annual mean sea surface temperature (SST) and winter (December to February) mean SST (blue line) in the Japan Basin of the East/Japan Sea from 1932 to 2009.

riverine sources (Shen et al., 2012). Davis et al. (2009) found that the DI and the mole percentages of $\beta$-Ala $+\gamma$-Aba were only effective indicators of DOM alteration during the later stages of decomposition. It appears the high variability in the DI and mole percentages of $\beta$-Ala $+\gamma$-Aba is consistent with the dynamic nature of this marginal sea.

\subsection{Bacterial contributions to DOM in the EJS}

The D-enantiomers of four amino acids (Ala, Glx, Asx, and Ser) are biomarkers of the bacterial origin of amino acids and DOM (McCarthy et al., 1998; Kaiser and Benner, 2008).
Of these amino acids, D-Ala and D-Asx concentrations were higher than those of D-Glx and D-Ser, and the concentrations of the four L-enantiomers were higher than those of the respective D-enantiomers in the EJS (Fig. 5 and Table 2). Similar patterns were observed at the BATS and HOT sites (Kaiser and Benner, 2008, 2009), but the concentrations of D-amino acids in deep waters of the EJS were higher than those at the BATS and HOT sites. The elevated concentrations of D-amino acids in deep waters are consistent with previous observations of the accumulation of marine humiclike fluorescent DOM in deep waters of the EJS (Kim and Kim, 2015, 2016).

Proteins are comprised of L-amino acids, whereas most Damino acids reside in a variety of non-protein biomolecules associated with the cell wall-membrane complex of bacteria (Schleifer and Kandler, 1972; Kaiser and Benner, 2008). Bioassay studies indicate D-amino acids are generally more resistant to decomposition than $\mathrm{L}$-amino acids, so the $\mathrm{D}: \mathrm{L}$ ratios of Ala, Glx, Asx, and Ser increase rapidly during bacterial growth and utilization of organic matter (Jørgensen et al., 1999; Amon et al., 2001; Kawasaki and Benner, 2006). The average $\mathrm{D}: \mathrm{L}$ ratios in surface waters $(0.73 \pm 0.22 \mathrm{Asx}$, $0.26 \pm 0.10 \mathrm{Glx}, 0.38 \pm 0.19 \mathrm{Ser}, 0.65 \pm 0.18 \mathrm{Ala})$ and deep waters $(0.61 \pm 0.21 \mathrm{Asx}, 0.23 \pm 0.10 \mathrm{Glx}, 0.37 \pm 0.26 \mathrm{Ser}$, $0.63 \pm 0.23 \mathrm{Ala})$ of the EJS were not significantly different $(p>0.05)$ (Fig. 5 and Table 2). The elevated D:L ratios in the EJS are indicative of the rapid utilization of proteina- 
ceous material and the accumulation of D-amino acids derived from bacteria.

Surface waters of the EJS have low DIN:DIP ratios $(<5)$ and low DIN concentrations $(<1 \mu \mathrm{M})$ in the mixed layer, and they are often dominated by cyanobacteria (Kim et al., 2010; Kim and Kim, 2013). It appears that cyanobacteria (Trichodesmium sp. and Synechococcus sp.) produce D-Ala and D-Glx, but not D-Asx or D-Ser (Kaiser and Benner, 2008). In addition to D-Ala and D-Glx, many heterotrophic marine bacteria also produced D-Asx and D-Ser (Kaiser and Benner, 2008). The elevated D : L ratios of these four biomarker amino acids in the EJS are consistent with major contributions from heterotrophic bacteria, but they do not preclude contributions from $\mathrm{N}_{2}$-fixing cyanobacteria, such as Trichodesmium spp., in surface waters.

The D:L ratios of Asx and Ala were somewhat elevated in surface waters of the EJS compared with those at the BATS and HOT sites, whereas the D : L ratios of Glx and Ser were elevated in deep waters at the HOT site (Fig. 6; Kaiser and Benner, 2008). The high D: L ratios of these biomarker amino acids throughout the water column of the EJS and the HOT and BATS sites indicate bacteria are an important source of amino acids, DOC, and DON in the global ocean (Kaiser and Benner, 2008; Benner and Herndl, 2011).

\subsection{Implications}

A trend of increasing average annual sea surface temperature and average winter sea surface temperature near Vladivostok, the most northern part of the Japan Basin, is synchronized with a warming trend $\left(2{ }^{\circ} \mathrm{C}\right)$ in winter air temperatures (December-February) from 1932 to 2009 in the EJS (Fig. 7). The warming of surface waters has led to a recent slowdown in deep-water formation in the EJS, which is well documented by changes in dissolved oxygen concentrations in deep water masses (Kim et al., 2001). As such, the rate of anthropogenic $\mathrm{CO}_{2}$ accumulation in the deep layer of the EJS has been decreasing considerably during the last few decades (1992-2007) owing to the shallowing of deepwater formation (Park et al., 2008). It is unknown whether this process also impacts bioavailable DOM accumulation in the deep EJS. However, our results suggest that the shallowing or slowdown of deep-water formation in response to atmospheric warming would bring about a substantial decline in the oceanic storage of bioavailable DOM and a consequent positive feedback in the climate system.

Data availability. Air temperature and SST used in Fig. 7 are freely available for download at https://www.nodc.noaa.gov/General/ temperature.html. Data are available on request by contacting the corresponding author.
Competing interests. The authors declare that they have no conflict of interest.

Acknowledgements. We would like to thank the captain, crew, and participants of the project titled "East Asian Seas Time series-I" (EAST-I) for assistance with the field sampling. This research was supported by the project titled "Long-term change of structure and function in marine ecosystems of Korea" funded by the Ministry of Oceans and Fisheries, Korea, and by the National Research Foundation (NRF) of Korea (NRF-2016R1C1B2006774). Ronald Benner and Yuan Shen acknowledge support from National Science Foundation (USA) grant 1233373.

Edited by: S. Pantoja

Reviewed by: J. Hawkes and two anonymous referees

\section{References}

Amon, R. M. W., Fitznar, H.-P., and Benner, R.: Linkages among the bioreactivity, chemical composition, and diagenetic state of marine dissolved organic matter, Limnol. Oceanogr., 46, 287297, 2001.

Bauer, J. E., Williams, P. M., and Druffel, E. R. M.: ${ }^{14} \mathrm{C}$ activity of dissolved organic carbon fractions in the north central Pacific and Sargasso Sea, Nature, 357, 667-670, 1992.

Benner, R.: Chemical composition and reactivity, edited by: Hansell, D. A. and Carlson, C. A., Biogeochemistry of marine dissolved organic matter, Academic Press, 2002.

Benner, R. and Herndl, G. J.: Bacterially derived dissolved organic matter in the microbial carbon pump, edited by: Jiao, N., Azam, F., and Sanders, S., Microbial Carbon Pump in the Ocean, Science/AAAS, Washington, DC, 2011.

Cowie, G. L. and Hedges, J. I.: Biochemical indicators of diagenetic alteration in natural organic-matter mixtures, Nature, 369, 304307, 1994.

Davis, J. and Benner, R.: Quantitative estimates of labile and semilabile dissolved organic carbon in the western Arctic Ocean: A molecular approach, Limnol. Oceanogr., 52, 2434-2444, 2007.

Davis, J., Kaiser, K., and Benner, R.: Amino acid and amino sugar yields and compositions as indicators of dissolved organic matter diagenesis, Org. Geochem., 40, 343-352, 2009.

Dauwe, B. and Middelburg, J. J.: Amino acids and hexosamines as indicators of organic matter degradation state in North Sea sediments, Limnol. Oceanogr., 43, 782-798, 1998.

Gamo, T.: Dissolved oxygen in the bottom water of the Sea of Japan as a sensitive alarm for global climate change, Trac-Trends Anal. Chem., 30, 1308-1318, 2011.

Hansell, D. A. and Carlson, C. A.: Deep-ocean gradients in the concentration of dissolved organic carbon, Nature, 395, 263-266, 1998.

Hansell, D. A. and Carlson, C. A.: Biogeochemistry of total organic carbon and nitrogen in the Sargasso Sea: control by convective overturn, Deep-Sea Res. II, 48, 1649-1667, 2001.

Harada, K. and Tsunogai, S.: Ra-226 in the Japan Sea and the residence time of the Japan Sea water, Earth Planet. Sc. Lett., 77, 236-244, 1986. 
Hong, G. H.: Time-series observation and sediment trap experiment, in: Development of Monitoring Technology for the wastes disposal sea areas, 3rd KORDI Report, Ansan, 1998.

Jenkins, W. J.: The biogeochemical consequences of changing ventilation in the Japan/East Sea, Mar. Chem., 108, 137-147, 2008.

Jørgensen, N. O. G., Tranvik, J. L. J., and Berg, G. M.: Occurrence and bacterial cycling of dissolved nitrogen in the Gulf of Riga, the Baltic Sea, Mar. Ecol.-Prog. Ser., 191, 1-8, 1999.

Kaiser, K. and Benner, R.: Hydrolysis induced racemization of amino acids, Limnol. Oceanogr. Meth., 3, 318-325, 2005.

Kaiser, K. and Benner, R.: Major bacterial contribution to the ocean reservoir of detrital organic carbon and nitrogen, Limnol. Oceanogr., 53, 99-112, 2008.

Kaiser, K. and Benner, R.: Biochemical composition and size distribution of organic matter at the Pacific and Atlantic time-series stations, Mar. Chem., 113, 63-77, 2009.

Kawasaki, N. and Benner, R.: Bacterial release of dissolved organic matter during cell growth and decline: molecular origin and composition, Limnol. Oceanogr., 51, 2170-2180, 2006.

Kim, J. and Kim, G.: Importance of colored dissolved organic matter (CDOM) inputs from the deep sea to the euphotic zone: Results from the East (Japan) Sea, Mar. Chem., 169, 33-40, 2015.

Kim, J. and Kim, G.: Significant anaerobic production of fluorescent dissolved organic matter in the deep East Sea (Sea of Japan), Geophys. Res. Lett., 43, 7609-7616, doi:10.1002/2016GL069335, 2016.

Kim, K., Kim, K.-R., Chung, J. Y., and Yoo, H. S.: Characteristics of physical properties in the Ulleung Basin, J. Kor. Soc. Oceanogr., 26, 83-100, 1991.

Kim, K., Kim, K.-R., Min, D.-H., Volkov, Y., Yoon, J.-H., and Takematsu, M.: Warming and structural changes in the East (Japan) Sea: A clue to future changes in global oceans?, Geophys. Res. Lett., 28, 3293-3296, 2001.

Kim, K.-R., Kim, G., Kim, K., Lobanov, V., and Ponamarev, V.: A sudden bottom-water formation during the severe winter 20002001: The case of the East/Japan Sea, Geophys. Res. Lett., 29, 1234, doi:10.1029/2001GL014498, 2002.

Kim, T. H. and Kim, G.: Factors controlling the C:N:P stoichiometry of dissolved organic matter (DOM) in the N-limited, cyanobacteria-dominated East/Japan Sea, J. Marine Syst., 115116, 1-9, 2013.

Kim, T. H., Lee, Y. W., and Kim, G.: Hydrographically mediated patterns of photosynthetic pigments in the East/Japan Sea: Low $\mathrm{N}: \mathrm{P}$ ratios and cyanobacterial dominance, J. Marine Syst., 82, 72-79, 2010.

Kim, T. H., Kim, G., Lee, S. A., and Dittmar, T.: Extraordinary slow degradation of Dissolved Organic Carbon (DOC) in a cold marginal sea, Sci. Rep., 5, 13808, doi:10.1038/srep13808, 2015.

Letscher, R. T., Hansell, D. A., Carlson, C. A., Lumpkin, R., and Knapp, A. N.: Dissolved organic nitrogen in the global surface ocean: Distribution and fate, Global Biogeochem. Cy., 27, 141153,2013

Loh, A. N. and Bauer, J. E.: Distribution, partitioning and fluxes of dissolved and particulate organic $\mathrm{C}, \mathrm{N}$ and $\mathrm{P}$ in the eastern North Pacific and Southern Oceans, Deep-Sea Res. I, 47, 2287-2316, 2000.
Martin, S., Munoz, E., and Drucker, R.: The effect of severe storms on the ice cover of the northern Tatarskiy Strait, J. Geophys. Res., 97, 17753-17764, 1992.

McCarthy, M. D., Hedges, J. I., and Benner, R.: Major bacterial contribution to marine dissolved organic nitrogen, Science, 281, 231-234, 1998.

Park, G. H., Lee, K., and Tishchenko, P.: Sudden, considerable reduction in recent uptake of anthropogenic $\mathrm{CO}_{2}$ by the East/Japan Sea, Geophys. Res. Lett., 20, GB4013, doi:10.1029/2008GL035672, 2008.

Postlethwaite, C. F., Rohling, E. J., Jenkins, W. J., and Walker, C. F.: A tracer study of ventilation in the Japan/East Sea, Deep-Sea Res. II, 52, 1684-1704, 2005.

Pujo-Pay, M., Conan, P., Oriol, L., Cornet-Barthaux, V., Falco, C., Ghiglione, J.-F., Goyet, C., Moutin, T., and Prieur, L.: Integrated survey of elemental stoichiometry $(\mathrm{C}, \mathrm{N}, \mathrm{P})$ from the western to eastern Mediterranean Sea, Biogeosciences, 8, 883899, doi:10.5194/bg-8-883-2011, 2011.

Schleifer, K. H. and Kandler, O.: Peptidoglycan types of bacterial cell walls and their taxonomic implications, Bact. Rev., 36, 407477, 1972.

Senjyu, T., Shin, H.-R., Yoon, J.-H., Nagano, Z., An, H.-S., Byun, S.-K., and Lee, C.-K.: Deep flow field in the Japan/East Sea as deduced from direct current measurements, Deep-Sea Res. Pt. II, 52, 1726-1741, 2005.

Sharp, J. H., Benner, R., Bennett, L., Carlson, C. A., Fitzwater, S. E., Peltzer, E. T., and Tupas, L. M.: Analyses of dissolved organic carbon in seawater: The JGOFS EqPac methods comparison, Mar. Chem., 41, 91-108, 1995.

Shen, Y., Fichot, C. G., and Benner, R.: Dissolved organic matter composition and bioavailability reflect ecosystem productivity in the Western Arctic Ocean, Biogeosciences, 9, 4993-5005, doi:10.5194/bg-9-4993-2012, 2012.

Shen, Y., Benner, R., Murray, A. E., Gimpel, C., Mitchell, G., Weiss, E., and Reiss, C.: Bioavailable dissolved organic matter and biological hot spots during austral winter in Antarctic waters, J. Geophys. Res., 122, 508-520, doi:10.1002/2016JC012301, 2017.

Talley, L. D., Lobanov, V., Ponomarev, V., Salyuk, A., Tishchenko, P., Zhabin, I., and Riser, S.: Deep convection and brine rejection in the Japan Sea, Geophys. Res. Lett., 30, 1159, doi:10.1029/2002GL016451, 2003.

Thomas, C., Cauwet, G., and Minster, J. F.: Dissolved organic carbon in the equatorial Atlantic Ocean, Mar. Chem., 49, 155-169, 1995.

Wakeham, S. G., Lee, C., Hedges, J. I., Hernes, P. J., and Peterson, M. L.: Molecular indicators of diagenetic status in marine organic matter, Geochim. Cosmochim. Ac., 61, 5363-5369, 1997.

Watanabe, Y. W., Watanabe, S., and Tsunogai, S.: Tritium in the Japan Sea and renewal time of the Japan Sea deep water, Mar. Chem., 34, 97-108, 1991.

Zehr, J., Waterbury, J., Turner, P., Montoya, J., Omoregie, E., Steward, G., Hansen, A., and Karl, D.: Unicellular cyanobacteria fix N2 in the subtropical North Pacific Ocean, Nature, 412, 635-638, 2001. 